P. Sedlacek, A. Forgac, E. Zaitseva

University of Žilina, Žilina, Slovakia

\title{
NEW MATRIX BASED ALGORITHM FOR CALCULATION OF IMPORTANCE MEASURES
}

\begin{abstract}
The system reliability/availability is complex term that is evaluated based on numerous indices and measures. There are different methods for the calculation of these indices and measures. Some of the most used are importance measures. These measures allow to evaluate the influence of fixed system components or set of components to the system reliability/availability. Importance measures are used to allow for various aspects of the impact of system elements on its failure or operability. Analysis of element importance is used in the system design, diagnosis, and optimization. In this paper new algorithm for the calculation some of importance measures is developed based on the matrix procedures. This paper goal is development of new algorithm to calculate importance measures of the system based on the matrix procedures that can be transformed in the parallel procedures/algorithm. This algorithm is developed based on the application of Logical Differential Calculus of Boolean logic for importance analysis of system. The application of parallel algorithm in importance analysis allows the evaluation of system of large dimension. Importance specific of the proposed matrix procedures for calculation of importance measures is the application of structure function for the mathematical representation of investigated system. This function defined the correlation of the system components states and system reliability/ availability. The structure function in this case is defined as truth vector to be used in the matrix transformation. The truth vector of Boolean function is column of the truth table of function if the values of the variables are lexicographically ordered.
\end{abstract}

Keywords: Structure function; Importance measures; Logical Differential Calculus; Direct Partial Boolean Derivatives.

\section{Introduction}

One of parts of the reliability analysis is importance analysis $[1,2]$. The importance analysis allows evaluation of influence of every system component to the system reliability or availability. This evaluation is implemented based the special indices that are named Importance Measures (IMs). IMs are used today to allow for various aspects of the impact of system elements on its failure or operability. Analysis of element importance is used in the system design, diagnosis, and optimization. There are different algorithms to compute these measures that are caused by the mathematical representation of investigated system [3]. The structure function has been introduced for system representation as one the first mathematical model and in case of the system analysis in stationary state can be interpreted as Boolean function [4]. This function maps the system components states and system state.

Authors of studies $[2,5,6]$ shown that the reliability analysis of system can be implemented by application of Logical Differential Calculus. The algorithms for calculation of frequency indices have been studied in [6]. The definition and computation of IMs based on Logical Differential Calculus, in particular Direct Partial Boolean Derivatives (DPBD), have been proposed and investigated in $[2,5]$. These derivatives allow investigating of the function value change depending on the change of the value of the function variable. The interpretation of the structure function in term of the Boolean function permits to study the system state change depending on the change of the failure or repairing of the component.

The computational complexity of the calculation of IMs based on the system structure function depends on the system dimension (number of system components). Authors of papers [5,7] propose to use the Binary
Decision Diagram (BDD) for the structure function representation to decrease the computational complexity of algorithms for reliability analysis. The application of BDD in importance analysis of system and IMs calculation have been considered in $[5,8]$. Other approach of this computational complexity decreasing is the use of parallel procedure $[9,10]$. The correlation of the parallel algorithms and matrix procedures has been studied in [11]. The transformation of traditional computational procedures for the calculation of indices and measures in matrix form is important step in the design of parallel algorithms. In this paper we consider and propose new definition of IMs based on the matrix procedure and algorithm for their calculation based on new definitions. This transformation of traditional definition of IMs into matrix form needs the special representation of structure function by matrix or vector. For this representation is used the truth vector of structure function introduced in [11] for definition of Boolean and Multiple-Valued functions. Some aspects of the matrix algorithms for calculation of DPBD have been investigated in [12]. In particular, the matrices to transform of truth vector of logical function into truth vector of logical derivative have been proposed. But author of [12] studied the Logical Differential Calculus for Multiple-valued logic and didn't considered specifics of Boolean logic, that is used in reliability analysis. The application of parallel algorithm in importance analysis allows the evaluation of system of large dimension.

\section{The structure function}

Let's a system consist of $n$ components. The system can have two possible state in point of view of its availability: working and failure. Every component state is designated as $x_{i}(i=1, \ldots, n)$ where the $i$-th component working state is interpreted as $x_{i}=1$ and $x_{i}=0$ indicates the component failure. The set of 
components states $\left(x_{1}, \ldots, x_{n}\right)$ is named the state vector. The system availability depends on components states. Every system component is characterized by the probability of its state. The probability of the $i$-th component failure is $q_{i}=\operatorname{Pr}\left\{x_{i}=0\right\}$. The probability of the $i$-th component working is $p_{i}=\operatorname{Pr}\left\{x_{i}=1\right\}=1-q_{i}$. These initial data allow analysis in stationary state that doesn't take into account the changes of the system and its components depending the time $[1,5,6]$.

The evaluation of the investigated system needs forming its mathematical representation. One of possible mathematical representation is the structure function, which maps the sets of components states system state. Taking into account the notations of components states the structure function $\varphi(x)$ of the system of $n$ components is defined as [5]:

$$
\varphi(\boldsymbol{x})=\varphi\left(x_{1}, \ldots, x_{n}\right): \quad\{0,1\}^{n} \rightarrow\{0,1\} .
$$

The system analysis takes into account next assumption [13]:

a) the system and its components have two states: up (working) and down (failed);

b) all system components are relevant to system;

c) the failure and repair rate of the components are constant;

d) repaired components are as good as new;

e) the system structure function is monotone nondecreasing that mean any component failure can not cause improve of the system working (reliability) $[4,6]$.

The equation of the structure function agrees with the Boolean function. It allows us to use mathematical approach of Boolean algebra for the structure function investigation. In particular, in papers $[2,5]$ the approach of Logical Differential Calculus has been used for importance analysis of the system represented by the structure function. In paper the analytical representation of the structure function in form of formula has been used. Such representation causes the specific of algorithms for calculation of importance measures. In this paper we propose to develop algorithms for calculation of importance measures based on the matrix procedures that can be transform into parallel regular algorithms. The application of parallel algorithms allows using proposed procedures for calculation of importance measures for system with large dimension.

The development of matrix procedures assumes the representation of initial data by matrix or vector. Therefore, the structure function should be defined by vector or matrix. In Boolean algebra there is the representation of Boolean function by truth vector [11]. The truth vector of Boolean function is column of the truth table of function if the values of the variables are lexicographically ordered $[11,12]$.

Therefore, the structure function of any system can be represented by truth vector of $2^{n}$ elements unambiguously:

$$
\mathbf{x}=\left[x^{(0)} x^{(1)} x^{(2)} \ldots x^{\left(2^{n}-1\right)}\right]^{\mathrm{T}} .
$$

For example, consider the trivial system of three components $(n=3)$ in Fig. 1 , a.

The structure function of this system is shown as truth table is shown in Fig. 1, b.
According to this truth table the truth vector of the structure function of the considered system

$$
\mathbf{x}=\left[\begin{array}{llllllll}
0 & 0 & 0 & 0 & 0 & 1 & 1 & 1
\end{array}\right]^{\mathrm{T}} .
$$

Let us mention the useful property of the truth vector. The number of the truth vector element in binary representation corresponds to values of function variables for this function value if components of the truth vector is number from 0 to $2^{n}-1$ [11]. For example, consider the truth vector element $x^{(5)}=1$ of the structure function of the system in Fig.1. The state vector for this function value is defined by the transformation of the parameter $i=5$ into binary representation:

$$
i_{10}=5 \Rightarrow\left(i_{1}, i_{2}, i_{3}\right)_{2}=(1,0,1) \text {. }
$$

Therefore, the state vector for the 5-th element of truth vector $\mathbf{x}$ of the considered structure function in Fig. 1 is $\left(x_{1} x_{2} x_{3}\right)=\left(\begin{array}{lll}1 & 0 & 1\end{array}\right)$. It allows us to declare that the element $x^{(5)}=1$ agrees with the structure function value $\varphi(1,0,1)=1$.

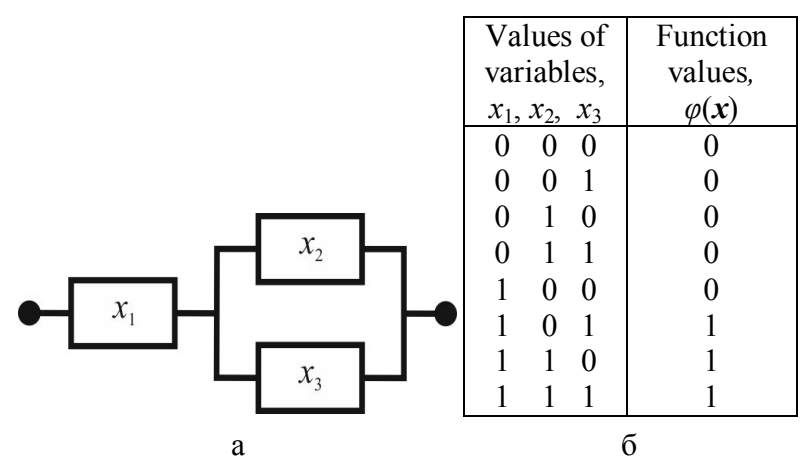

Fig. 1. Example of system (a) and its structure function's truth table (б)

\section{Logical Differential Calculus}

A Logical Differential Calculus is part of algebra logic for investigation of dynamic properties of logical function by logical derivatives. There are different types of logical derivatives $[14,15]$. One of them is logical derivatives that is often interpreted as logical difference and defined by equation:

$$
\frac{\partial \varphi(x)}{\partial x_{i}}=\varphi\left(0_{i}, \boldsymbol{x}\right) \oplus \varphi\left(1_{i}, \boldsymbol{x}\right),
$$

where symbol $\oplus$ is operation XOR and the operand $\varphi\left(0_{i}\right.$, $\boldsymbol{x})$ is the structure function value when the $i$-th component is in state $0\left(x_{i}=0\right)$, and the second operand $\varphi\left(1_{i}, \boldsymbol{x}\right)$ is the structure function value when the $i$-th component is in state $1\left(x_{i}=1\right)$.

This type of derivatives allows us to investigate the result of the system component state change, but this derivative is not fixed the direction of the state change. This flaw can be leveled by the use of other type of logical derivatives that is named Direct Partial Boolean Derivatives (DPBD) [14].

In analysis of Boolean functions, a DPBD allows identifying situations in which the change of a Boolean variable results the change of the value of Boolean function. In case of reliability analysis, DPBD allows investigation the influence of a structure function variable (=component state) change on a function value change 
(=system state). Therefore, a DPBD of the structure function permits indicating components states (state vectors) for which the change of one component state causes a change of the system state (availability) [2].

DPBD can be used to analyze how a specific change of component state (from 0 to 1 or from 1 to 0 ) affects the system functionality (from 0 to 1 or from 1 to 0 ). This derivative for the system structure function change from $j$ to $\bar{j}$ with respect to variable $x_{i}$ change from $a$ to $\bar{a}$ is defined as:

$$
\frac{\partial \varphi(j \rightarrow \bar{j})}{\partial x_{i}(a \rightarrow \bar{a})}=\left\{\varphi\left(a_{i}, \boldsymbol{x}\right) \leftrightarrow j\right\} \wedge\left\{\varphi\left(\bar{a}_{i}, \boldsymbol{x}\right) \leftrightarrow \bar{j}\right\},
$$

where $\varphi\left(a_{i}, \boldsymbol{x}\right)=\varphi\left(x_{1}, x_{2}, \ldots, x_{i-1}, a, x_{i+1}, \ldots, x_{n}\right)$,

$a, j \in\{0,1\}$;

$\leftrightarrow$ is the symbol of equivalence operator (logical biconditional);

$\wedge$ denotes Boolean operation AND;

$\bar{a}$ is a negation of the argument $a$.

The matrix interpretation of DPBD can be introduced for the truth vector of DPBD that is calculated based on the truth vector of the structure function. According to the definition of the DPBD $\partial \varphi(j \rightarrow \bar{j}) / \partial x_{i}(a \rightarrow \bar{a})$ the truth vector of this derivative is calculated as [12]:

$$
\frac{\partial \mathbf{x}(j \rightarrow \bar{j})}{\partial x_{i}(a \rightarrow \bar{a})}=\left(\mathbf{P}^{(i, a)} \cdot \lambda_{j}(\mathbf{x})\right) \cdot\left(\mathbf{P}^{(i, \bar{a})} \cdot \lambda_{\bar{j}}(\mathbf{x})\right),
$$

where $\mathbf{x}$ is the truth vector of the structure function;

$\lambda_{s}(\mathbf{x})$ is the vector literal calculated according to:

$$
\begin{aligned}
& \lambda_{s}(\boldsymbol{x})=\lambda_{s}\left(\left[x^{(0)} x^{(1)} \ldots x^{\left(2^{n}-1\right)}\right]^{\mathrm{T}}\right)= \\
& \left.=\left[s \leftrightarrow x^{(0)} s \leftrightarrow x^{(1)} \ldots s \leftrightarrow x^{\left(2^{n}-1\right)}\right)\right]^{\mathrm{T}} \text {, for } s \in\{j, \bar{j}\} ;
\end{aligned}
$$

$\mathbf{P}^{(i, l)}$ is differentiation matrix of the dimension $2^{n-1} \times 2^{n}$ of the variable $x_{i}$ for $l \in\{a, \bar{a}\}$ that is formed as:

$$
\mathbf{P}^{(i, l)}=\mathbf{M}_{i-1} \otimes[l \leftrightarrow 0 \quad l \leftrightarrow 1] \otimes \mathbf{M}_{n-i},
$$

matrices $\mathbf{M}_{i-1}$ and $\mathbf{M}_{n-i}$ are diagonal matrices of the dimension $2^{i-1} \times 2^{i-1}$ and $2^{n-i} \times 2^{n-i}$ accordantly.

The vector literals $\lambda_{j}(\mathbf{x})$ and $\lambda_{j}(\mathbf{x})$ indicate the variables values (state vectors) for which the structure function has value $j$ and $\bar{j}$ (the system state $j$ and $\bar{j}$ ) accordantly. The matrices $\mathbf{P}^{(i, a)}$ and $\mathbf{P}^{(i, \bar{a})}$ indicate the variables values (state vectors) for which value $x_{i}$ is $a$ and $\bar{a}$.

For example, compute the truth vector of the DPBD with respect to the variable $x_{2}$ $\partial \mathbf{x}(1 \rightarrow 0) / \partial x_{2}(1 \rightarrow 0)$ for the structure function of the system shown in Fig.1. The truth vector of this system structure function is $\mathbf{x}=\left[\begin{array}{lllllll}0 & 0 & 0 & 0 & 0 & 1 & 1\end{array}\right]^{\mathrm{T}}$. According to the equation for the calculation of truth vector of DPBD we obtain:

$$
\frac{\partial \mathbf{x}(1 \rightarrow 0)}{\partial x_{2}(1 \rightarrow 0)}=\left(\mathbf{P}^{(2,1)} \cdot \lambda_{1}(\mathbf{x})\right) \cdot\left(\mathbf{P}^{(2,0)} \cdot \lambda_{0}(\mathbf{x})\right),
$$

where vector literals are $\lambda_{1}(\mathbf{x})=\left[\begin{array}{llllllll}0 & 0 & 0 & 0 & 0 & 1 & 1 & 1\end{array}\right]^{\mathrm{T}}$ and

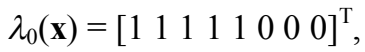

$$
\begin{aligned}
& \mathbf{P}^{(2,1)}=\mathbf{M}_{1} \otimes\left[\begin{array}{ll}
0 & 1
\end{array}\right] \otimes \mathbf{M}_{1}= \\
& =\left[\begin{array}{ll}
1 & 0 \\
0 & 1
\end{array}\right] \otimes\left[\begin{array}{ll}
0 & 1
\end{array}\right] \otimes\left[\begin{array}{ll}
1 & 0 \\
0 & 1
\end{array}\right]=\left[\begin{array}{cccccccc}
0 & 0 & 1 & 0 & 0 & 0 & 0 & 0 \\
0 & 0 & 0 & 1 & 0 & 0 & 0 & 0 \\
0 & 0 & 0 & 0 & 0 & 0 & 1 & 0 \\
0 & 0 & 0 & 0 & 0 & 0 & 0 & 1
\end{array}\right], \\
& \mathbf{P}^{(2,0)}=\mathbf{M}_{1} \otimes\left[\begin{array}{ll}
1 & 0
\end{array}\right] \otimes \mathbf{M}_{1}= \\
& =\left[\begin{array}{ll}
1 & 0 \\
0 & 1
\end{array}\right] \otimes\left[\begin{array}{ll}
1 & 0
\end{array}\right] \otimes\left[\begin{array}{ll}
1 & 0 \\
0 & 1
\end{array}\right]=\left[\begin{array}{cccccccc}
1 & 0 & 0 & 0 & 0 & 0 & 0 & 0 \\
0 & 1 & 0 & 0 & 0 & 0 & 0 & 0 \\
0 & 0 & 0 & 0 & 1 & 0 & 0 & 0 \\
0 & 0 & 0 & 0 & 0 & 1 & 0 & 0
\end{array}\right] .
\end{aligned}
$$

$\frac{\partial \mathbf{x}(1 \rightarrow 0)}{\partial x_{2}(1 \rightarrow 0)}=\left(\mathbf{P}^{(2,1)} \cdot \lambda_{1}(\mathbf{x})\right) \cdot\left(\mathbf{P}^{(2,0)} \cdot \lambda_{0}(\mathbf{x})\right)=\left[\begin{array}{l}0 \\ 0 \\ 1 \\ 1\end{array}\right] \cdot\left[\begin{array}{l}1 \\ 1 \\ 1 \\ 0\end{array}\right]=\left[\begin{array}{l}0 \\ 0 \\ 1 \\ 0\end{array}\right]$.

The truth vector of DPBD $\partial \mathbf{x}(1 \rightarrow 0) / \partial x_{2}(1 \rightarrow 0)$ doesn't depend on the variable $x_{2}$ and has only one nonzero value that agree with the variables values: $x_{1}=1$ and $x_{3}=0$. The state vector $\left(x_{1} x_{3}\right)=\left(\begin{array}{ll}1 & 0\end{array}\right)$ allows us to declare only one situation of the system failure depending the fault of the second component. It is possible if the first component is in the working state and the third component was fault before the breakdown of the second component.

The truth vectors of other DPBDs of this system for analysis of its failure can be calculated similar.

\begin{tabular}{|c|c|c|c|}
\hline $\begin{array}{c}\text { Variables } \\
\text { values, } \\
x_{1} x_{2} x_{3}\end{array}$ & $\frac{\partial \mathbf{x}(1 \rightarrow 0)}{\partial x_{1}(1 \rightarrow 0)}$ & $\frac{\partial \mathbf{x}(1 \rightarrow 0)}{\partial x_{2}(1 \rightarrow 0)}$ & $\frac{\partial \mathbf{x}(1 \rightarrow 0)}{\partial x_{3}(1 \rightarrow 0)}$ \\
\hline $\begin{array}{llll}0 & 0 & 0\end{array}$ & - & - & - \\
\hline $\begin{array}{lll}0 & 0 & 1\end{array}$ & - & - & 0 \\
\hline $\begin{array}{lll}0 & 1 & 0\end{array}$ & - & 0 & - \\
\hline $\begin{array}{llll}0 & 1 & 1\end{array}$ & - & 0 & 0 \\
\hline $\begin{array}{lll}1 & 0 & 0\end{array}$ & 0 & - & - \\
\hline $\begin{array}{lll}1 & 0 & 1\end{array}$ & 0 & - & 1 \\
\hline $\begin{array}{lll}1 & 1 & 0\end{array}$ & 0 & 1 & - \\
\hline $\begin{array}{lll}1 & 1 & 1\end{array}$ & 1 & 0 & 1 \\
\hline
\end{tabular}
According to these derivatives, the considered system fails depending the fault of the second component in case if the third component was not functioning and the first component has been working. The fault of the third component cause the system failure in two situations: the first component should be in the working state and the second component can be fault or working.

Table 1 - The truth vectors of DPBDs for the system failure analysis (the system is shown in Fig. 1)

\section{Importance Measures}

One of the first of Importance Measures (IMs) has been introduced by Birnbaum [16]. These measures allow evaluating the influence of the fixed system component changes (failure or restore) to the system failure or working. In paper [2] new DPBDs-based method for 
calculation of IMs has been developed. The well-known IM as Birnbaum Importance (BI), Structure Importance (SI) and Criticality Importance (CI) have been defined in terms of DPBD. Let us summarize these definitions of IMs (Table 2) for the system failure based on DPBDs.

According to the definition of SI in Table 2 this measure can be considered as relative number of situations in which a given component is critical for the system activity. It can be defined as proportion of system state for which the fault of the fixed component causes the system failure in space of possible system states. The number of such caused system state can be defined by DPBD $\partial \varphi(1 \rightarrow 0) / \partial x_{i}(1 \rightarrow 0)$ and nominated as $\rho_{i}^{(1 \rightarrow 0)}$. The SI of the $i$-th component is defined as [2]:

$$
S I_{i}=\rho_{i}^{(1 \rightarrow 0)} / 2^{n-1},
$$

where $2^{n}-1$ is a size of the DPBD.

\section{Table 2 - Importance Measures Definitions}

\begin{tabular}{|c|l|}
\hline $\begin{array}{c}\text { Importance } \\
\text { Measure }\end{array}$ & \multicolumn{1}{c|}{ Meaning } \\
\hline SI & $\begin{array}{l}\text { The SI concentrates only on the topological } \\
\text { structure of the system. It is defined as the } \\
\text { probability of the system failure depending } \\
\text { on the failure of the component breakdown } \\
\text { based on the topological specific of the } \\
\text { system }\end{array}$ \\
\hline BI & $\begin{array}{l}\text { The BI of a given component is defined as } \\
\text { the probability that the component is } \\
\text { critical for the system work. }\end{array}$ \\
\hline CI & $\begin{array}{l}\text { The CI of a given component is calculated } \\
\text { as the probability that the system failure has } \\
\text { been caused by the component failure, } \\
\text { given that the system is failed. }\end{array}$ \\
\hline
\end{tabular}

The BI of component $i$ defines as the probability that the $i$-th system component is critical for system failure. It is probability of the system failure if the $i$-th system component was fault. This probability can be defined as the probability of all critical states. These states is computed by the DPBD $\partial \varphi(1 \rightarrow 0) / \partial x_{i}(1 \rightarrow 0)[2]$ :

$$
B I_{i}=\operatorname{Pr}\left\{\partial \varphi(1 \rightarrow 0) / x_{i}(1 \rightarrow 0) \leftrightarrow 1\right\} .
$$

One very often used IM is CI. This measure is defined similar to the BI, but take into account of the probability of the $i$-th component fault [1]. Therefore, this measure can be calculated based on DPBD to:

$$
C I_{i}=B I_{i} \cdot\left(q_{i} / U\right) \text {. }
$$

where $q_{i}$ is the probability of the $i$-th component fault and $U$ is the system unavailability that is calculated based on the structure function as:

$$
U=\operatorname{Pr}\{\varphi(\boldsymbol{x})=0\} .
$$

The considered IMs are computed based on the DPBD. The definition of the structure function by truth vector allows us to compute these measures based on the matrix procedures.

\section{Matrix procedures for Importance Measures calculation}

The SI of the $i$-th component can be computed by the matrix procedure as:

$$
S I_{i}=O_{\neq 0}\left(\partial \mathbf{x}(j \rightarrow \bar{j}) / \partial x_{i}(a \rightarrow \bar{a})\right) / 2^{n-1},
$$

where $O_{\neq 0}$ is number of non-zero values of the truth vector of DPBD $\partial \mathbf{x}(j \rightarrow \bar{j}) / \partial x_{i}(a \rightarrow \bar{a})$.

The BI of the $i$-th component is defined as the probability of all critical states that are indicated by non-zero values of the truth vector of DPBD:

$$
B I_{i}=\operatorname{Pr}\left\{\partial \mathbf{x}(1 \rightarrow 0) / x_{i}(1 \rightarrow 0) \leftrightarrow 1\right\} .
$$

The CI of the $i$-th component is calculated based on BI. A matrix procedure can be transform in parallel procedure according to [12].

To illustrate the analysis of system based on SI, BI and CI using DPBDs consider the system in Fig. 1 and compute these measures for all system components. Values of IMs for this system are computed in Table 3. According to these IMs, the first component has the most influence on the system failure from point of view of the system structure, because the values of the SI, BI are greatest for this component. The CI is maximal for the second and third components and, therefore, it indicates the first component as non-important taking into account the probability of failure of this component (it is minimal for this component, i.e. $\left.q_{1}=\left(1-p_{i}\right)=0.10\right)$.

Table 3 - IMs for the system in Fig.1

\begin{tabular}{|l|c|c|c|}
\hline Component & $x_{1}$ & $x_{2}$ & $x_{3}$ \\
\hline Probability of component state, $p_{i}$ & 0.90 & 0.70 & 0.65 \\
\hline $\mathrm{SI}_{i}$ & 0.75 & 0.25 & 0.25 \\
\hline $\mathrm{BI}_{i}$ & 0.90 & 0.32 & 0.27 \\
\hline $\mathrm{CI}_{i}$ & 0.46 & 0.49 & 0.49 \\
\hline
\end{tabular}

So, DPBDs are one of possible mathematical approaches that can be used in importance analysis, and they allow us to calculate all often used IMs (Table 2). Mathematical background of its application for the definition of IM has been considered in papers [2, 5]. In this paper new algorithm for the calculation of DPBD based on a parallel procedure is developed.

\section{Conclusion}

In this paper the new algorithm шы proposed for the calculation of IMs based on the matrix procedures. This algorithm is based on the use of the DPBDs. The computational complexity of the proposed algorithm is less in comparison with algorithm based on the typical analytical calculation (Fig. 2).

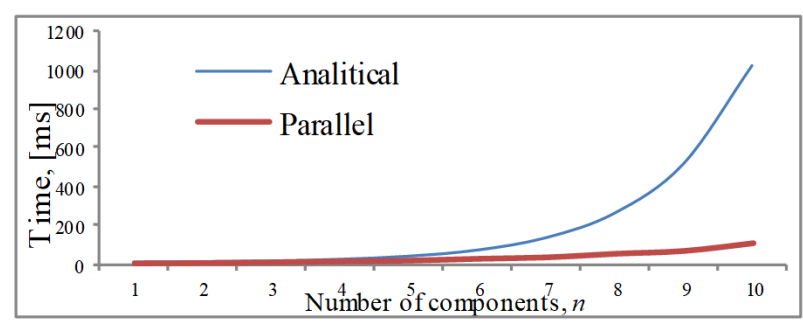

Fig. 2. Computation time for calculation of DPBDs based on analytical and parallel procedures

The proposed algorithm for the calculation of IMs based on the parallel procedures can be used in many practical applications. 


\section{Acknowledgement}

The Slovak Research and Development Agency (Agentúra na Podporu Výskumu a Vývoja) supported this work under the contract no. APVV-18-0027 titled "New methods development for reliability analysis of complex system".

\section{REFERENCES}

1. Kuo, W., Zhu, X. Importance Measures in Reliability, Risk and Optimization, John-Wiley \& Sons Publ., 2012. 440 p.

2. Zaitseva, E., Levashenko, V. Importance Analysis by Logical Differential Calculus. Automation and Remote Control, 2013, vol. 74, no. 2, pp. 171-182.

3. Levitin, G. Lisnianski, A. Multi-state System Reliability Analysis and Optimization, Handbook of Reliability Engineering, London, Berlin, NY, Springer Publ., 2003. 342 p.

4. Barlow, R. E., Proschan, F. Importance of system components and fault tree events. Stochastic Processes and their Applications, 1975, vol. 3, no. 2, pp. 153-173.

5. Kvassay, M., Levashenko, V., Zaitseva, E. Analysis of minimal cut and path sets based on direct partial Boolean derivatives. Proceedings of the Institution of Mechanical Engineers, Part O: Journal of Risk and Reliability, 2016, vol. 230, no. 2, pp.147-161.

6. Schneeweiss, W.G. A short Boolean derivation of mean failure frequency for any (also non-coherent) system, Reliability and Engineering System Safety, 2009, vol. 94, no. 8, pp. 1363-1367.

7. Zhang, L., Xing, L., Liu, A., Mao, K. Multivalued Decision Diagrams-Based Trust Level Analysis for Social Networks, IEEE Access, 2019, vol. 7, no. 12, pp. 180620-180629.

8. Zhang, S., Sun, S., Si, S., Wang, P. A decision diagram based reliability evaluation method for multiple phased-mission systems. Eksploatacja i Niezawodnosc - Maintenance and Reliability, 2017, vol. 19, no. 3, pp. 485-492.

9. Xin, S., Yan, C., Xingyou, Z., Chuanzhi, W. A novel multi-microgrids system reliability assessment algorithm using parallel computing. Energy Internet and Energy System Integration: Proceedings of the 2017 IEEE Conference, Beijing, China, 2017, pp. 1-6.

10. Quan, Z. Wang, Z.-J., Ye, T., Guo, S. Task Scheduling for Energy Consumption Constrained Parallel Applications on Heterogeneous Computing Systems. IEEE Transactions on Parallel and Distributed Systems, 2019, vol. 45, no. 12, pp. 1-8.

11. Kukharev, G. Shmerko, V., Zaitseva, E. Multiple-Valued Data Processing Algorithms and Systolic Processors. Minsk, Nauka and Technika Publ., 1990. 320 p.

12. Zaitseva, E., Levashenko, V. Reliability analysis of Multi-State System and Multiple-Valued Logic. International Journal of Quality \& Reliability Management, 2017, vol. 34, no. 6, pp. 862-878.

13. Beeson, S., Andrews, J. D. Importance measure for non-coherent-system analysis. IEEE Transaction on Reliability, 2003, vol. 52, no. 3, pp. 301-310.

14. Steinbach, B., Posthoff, C. Boolean Differential Caculus. San Rafael, Morgan \& Claypool Publ., 2018. 720 p.

15. Posthoff, C., Steinbach, B. Logic Functions and Equations: Binary Models for Computer Science. Second ed., Springer Publ., 2019. $507 \mathrm{p}$.

16. Moret, B. M. E., Thomason, M. G. Boolean Difference Techniques for Time-Sequence and Common-Cause Analysis of Fault-Trees. IEEE Transaction on Reliability, 1984, vol. R-33, pp. 399-405.

17. Birnbaum Z. W. On the Importance of Different Components in a Multicomponent System. Multivariate Analysis II. New York, Academic Press Publ., 1969, pp. 581-922.

\section{Матричні процедури \\ для обчислення важливісних оцінок компонентів системи}

П. Седлячек, А. Форгач, О. Зайцева

Анотація. Надійність/доступність системи є складним багатогранним поняттям, яка оцінюється на основі численних показників і індексів. Існують різні методи розрахунку цих показників в аналізі надійності. Одними 3 найбільш часто використовуваних показників $\epsilon$ показниками оцінки важливості компонентів системи, які дозволяють оцінити вплив одного або декількох компонентів системи на ії надійність/доступність. Сьогодні використовуються міри важливості, щоб врахувати різні аспекти впливу елементів системи на іiі відмову або працездатність. Аналіз важливості елементів використовується при проектуванні, діагностиці та оптимізації системи. У даній статті розроблені нові алгоритми розрахунку деяких оцінок важливості компонентів системи на основі матричних процедур. Метою даної роботи $\epsilon$ розробка нового алгоритму для розрахунку показників важливості системи на основі матричних процедур, які можуть бути перетворені в паралельні процедури/алгоритми. Ці алгоритми розроблені на основі застосування логічного диференціального обчислення булевої логіки для аналізу важливості системи. Застосування паралельних алгоритмів в аналізі важливості дозволяє оцінювати надійність системи великої розмірності. Специфічною особливістю запропонованих матричних процедур для розрахунку показників важливості є використання структурної функції для математичного подання досліджуваної системи. Ця функція визначає однозначне співвідношення для всіх можливих поєднань станів компонентів системи і надійністю/доступністю системи. Структурна функція в цьому випадку визначається як вектор істинності, який використовується в матричних перетвореннях. Вектор істинності булевої функції являє собою стовпець таблиці істинності для значень змінних упорядкованих в лексикографічному порядку. Будь-яка структурна функція системи може бути однозначно представлена вектором істинності, який складається $32^{\mathrm{n}}$ елементів.

Ключові слова: оцінки важливості компонентів; структурна функція; логічне диференціальне числення; логічні спрямовані похідні. 